\title{
In vitro screening of white Jute (Corchorus capsularis L) against salinity stress
}

\author{
M. Ramesh Naik ${ }^{1 *}$, Mukesh Kumar ${ }^{1}$, D. Barman ${ }^{1}$, P.N. Meena ${ }^{1}$, A. Anil Kumar ${ }^{2}$ and \\ D. K. Kundu ${ }^{1}$
}

${ }^{1}$ Crop Production Division, ICAR-Central Research Institute for Jute and Allied Fibre, Barrackpore, Kolkata-700 120 (West Bengal), INDIA.

${ }^{2}$ Crop Improvement Division, ICAR-Central Research Institute for Jute and Allied Fibre, Barrackpore, Kolkata-700 120 (West Bengal), INDIA.

*Corresponding author. E-mail: rameshag16@gmail.com

Received: December 3, 2014; Revised received: April 15, 2015; Accepted: May 2, 2015

\begin{abstract}
The environmental stress such as salinity of soil or water is serious threat for field crops in the world, especially in arid and semiarid regions. To study salinity stress on jute (Corchorus capsularis), an experiment was laid out in factorial randomized block design keeping nine capsularis varieties (JRC-698, JRC-321, JRC-517, JRC-7447, JBC-5, JRC-212, JRC-80, JRC-532 and UPC-94) as one factor and four levels of salt concentrations i.e. control (Distilled $\mathrm{H}_{2} \mathrm{O}$ ), 100,160, 240 and $300 \mathrm{mM} \mathrm{NaCl}$ with three replications. Adverse effect of salinity increased with increasing concentration of sodium chloride. Among nine jute varieties the highest germination percentage $(89.5 \%)$, root length $(0.6 \mathrm{~cm})$, shoot length $(1.2 \mathrm{~cm})$, fresh weight $(93 \mathrm{mg})$ and dry weight $(9.5 \mathrm{mg})$ of seedling were observed in 'JRC-698' at salt concentration at $160 \mathrm{mM} \mathrm{NaCl}$ as compared with other salt concentration. All growth parameters were recorded higher in control than other treatments. All growth parameters were decreased up to 240 $\mathrm{mM} \mathrm{NaCl}$ concentration and it was completely inhibited at $300 \mathrm{mM} \mathrm{NaCl}$. Variety 'UPC-94' was the most susceptible to salinity stress. Hence, white jute varieties, JRC-698 and JRC-517 can be grown at $160 \mathrm{mM} \mathrm{NaCl}$ concentration.
\end{abstract}

Keywords: Corchorus capsularis, Germination percentage, Salinity stress, Salt tolerance index (STI)

\section{INTRODUCTION}

Salinity and drought are common environmental stresses that adversely effects on crop production and life quality. Salinity has reached a level of $19.5 \%$ of all irrigated agricultural land worldwide (FAO, 2005). One of the most important abiotic factors limiting plant germination and early seedling stage is water stress brought about by drought and salinity (Almansouri et al., 2001). Increased salinization of arable land is expected to have devastating global effect, with prediction of $30 \%$ land loss within the next 25 years, and up to $50 \%$ by the year 2050 (Wang et al., 2008). This factor may give the true picture of the crop performance in the natural field conditions. Saline soil water inhibits plant growth by osmotic effect, which reduces the ability of plant to take up water and by ion excess, which affects the plant cells (Munns, 2005). According to Fitter and Hay (1987), plants resist salinity by four different ways i) phonological escape (seasonal adoption) ii) exclusion (selective absorption) often seen in halophytes iii) amelioration (selective localisation) and iv) tolerance (stress acceptance).

Jute is the most important bast fibre crop of the world being cultivated in Eastern India, Bangladesh, Nepal and some South East Asian countries, and is second only to cotton in terms of production and variety of uses (Islam et al., 2013). Jute crop plays a pivotal role in the farming economy of number of eastern Indian states like West Bengal, Assam, Bihar and Odisha (Maji et al., 2012). Entire life-cycle of jute from cultivation to usage and disposal, it is friendly to the environment and produces no toxic material (Sarkar, 2008). Recent hurricanes like Alia in India and Bangladesh has converted vast non-saline crop lands to saline soils (Anonymous, 2010) and this salinity is still increasing day by day due to raise in sea level because of global warming (www.savebd.com). In recent years, requirement for jute fibre has tremendously increased in china. Jute can grow readily in saline soils (Ma et al., 2009). Main concern in jute fiber production system in India is the non-uniform productivity over 87 jute-growing districts located in varying agro-climatic regions of the country. The foremost reasons for such yield gap are the non-uniform productivity due to abiotic factors and non-adoption of recommended package of practices. There is an urgent need for developing crops with greater tolerance to environmental stresses, so necessity of evaluation of salinity tolerant plants is important at plant growth stage. One of the common tests in laboratories is the evaluation of seeds germination response to different 
$\mathrm{NaCl}$ concentrations (Bohnert et al., 1995). The present study was carried out to find out the effect of salt stress on nine selected white jute (C. capsularis) varieties and to screen relatively better salt tolerant varieties.

\section{MATERIALS AND METHODS}

The experiment was conducted under laboratory conditions. Twenty five representative seeds per varieties were placed on a filter paper in $9 \mathrm{~cm}$ petri dish. One set of 45 petridishes was considered as one replication. Petri dish containing $8 \mathrm{ml}$ of distilled water (control) or $8 \mathrm{ml}$ of 100, 160, 240 and $300 \mathrm{mM} \mathrm{NaCl}$ concentration. Seeds were germinated at room temperature $\left(27^{\circ} \mathrm{C} \pm 2\right)$. The seed germination was investigated after every 12 hours. The seeds were considered germinated when there was radical protrusion through the seed coat. The lengths of root and shoot of the germinated seeds were recorded by using scale. Fresh weight was measured with weighing balance and it was oven dried at $60{ }^{\circ} \mathrm{C}$ for 24 hours to acquired mean dry weight (Seghatoleslami, 2010). Numbers of germinated seeds were counted every day and recorded germination rate. Below formula was used when determining germination rate (Pieper, 1952).

$\mathrm{GR}=\{(\mathrm{n} 1 \times \mathrm{t} 1)+(\mathrm{n} 2 \times \mathrm{t} 2)+(\mathrm{n} 3 \times \mathrm{t} 3)+\ldots \ldots \ldots(\mathrm{n} 3 \times \mathrm{t} 3)\} / \mathrm{T}$

Whereas,

GR: Germination rate, $\mathrm{n}$ : Number of days for each counting of germinated seeds, $t$ : Number of germinated seeds in each counting day and $\mathrm{T}$ : Total number of germinated seeds.

Salt tolerance index (STI) was calculated according to Kagan et al. (2010) as total plant (shoot + root) dry weight obtained from 5 seeds grown on different salt concentrations compared to total plant dry weight obtained on normal concentration.

$\mathrm{STI}=\left(\mathrm{TDW}\right.$ at $\mathrm{S}_{\mathrm{x}} / \mathrm{TDW}$ at $\left.\left.\mathrm{S}_{1}\right) \times 100\right]$

Whereas,

$\mathrm{STI}=$ salt tolerance index, $\mathrm{TDW} \mathrm{S}_{1}=$ total dry weight at control and TDW $\mathrm{S}_{\mathrm{x}}=$ total dry weight at treatment

\section{RESULTS AND DISCUSSION}

According to Hongyu et al., (2011) salt tolerance of germination stage of jute was consistency with that of seedling stage. At low salt concentrations, germination are mildly affected or not affected at all, since most varieties will not grow in high concentrations of salt and are severely inhibited at 240 and $300 \mathrm{mM} \mathrm{NaCl}$. Germination is a critical stage in the lifecycle of crops and salinity tolerance at this stage is crucially important for the establishment of the plants growing in such environments. Germination percentage declined sharply with 100 and $160 \mathrm{mM} \mathrm{NaCl}$ concentration. At these $\mathrm{NaCl}$ concentrations, differences among the varieties were non-significant. Varieties JRC-698, JRC-517 and JRC-532 had higher germination percentages $80 \%$ than even with the $160 \mathrm{mM} \mathrm{NaCl}$ concentration, while UPC-94 had lower germination percentages with the same $\mathrm{NaCl}$ concentration (Table 1). Even though salt tolerance during germination differs from that at later stages of plant development (Hongyu et al., 2011), good germination under saline conditions is essential because it is the first stage of plant growth. Also $\mathrm{NaCl}$ may be inhibitory to the activities of some enzymes that may play critical roles in seed germination.

Germination rate significantly increased $(\mathrm{P} \leq 0.05)$ by increasing the $\mathrm{NaCl}$ concentrations, it was observed highest at $240 \mathrm{mM} \mathrm{NaCl}$. Later it will be decreased by reducing the $\mathrm{NaCl}$ concentration levels. In case of variety germination rate was higher in JRC-80 at 240 $\mathrm{mM} \mathrm{NaCl}$. There were no significant differences between varieties in terms of root and shoot lengths. Root and shoot length was higher in control than other salt concentration levels, but later on showed a declining trend at higher levels of salinity and a perfect negative correlation with increasing levels of $\mathrm{NaCl}$ (Tables 1 and 2). Higher root $(0.84 \mathrm{~cm})$ and shoot $(0.33 \mathrm{~cm})$ length was observed in varieties JRC-698 even at 240 $\mathrm{mM} \mathrm{NaCl}$. The decreased in root and shoot length starting from the $100 \mathrm{mM} \mathrm{NaCl}$ concentration, was considered an indicator that root and shoot growth was affected more quickly compared to control (Abass and Latif, 2005). High concentrations of salts to disturb the capacity of roots to extract water and high salts within the plant itself can be toxic resulting in an inhibition of many physiological and biochemical processes such as nutrient uptake and assimilation and thereby reduced plant growth, development and survival (Munns and Tester, 2008). Moreover, saline condition disturbs water uptake by seed, resulting in the reduction of plant hormones and enzymes production which consequently inhibits seedling's growth (Younis et al., 2008). Seedling fresh and dry weight (Table 2) was higher in JRC-698. However, shoot and root weight did not always relate to shoot and root length, because some varieties had long shoots and roots, thin and unbranched, they could not produce sufficient dry weight. It is anticipated that in addition to higher dry weight, longer and stronger root and shoot development will allow more successful selection for high salt tolerance. However, as selection criteria, the length and weight measurements taken from single plants can be considered appropriate only when there is a high germination percentage. For these reasons, germination percentage and total dry weight, was determined to be a more reliable selection criterion in this study. Salt tolerance index was differ significantly $(\mathrm{P} \leq 0.05)$ among the varieties were obvious with the salt treatments (Table 3). The salt tolerance index varied between $52 \%$ and $78 \%$ with 160 and $100 \mathrm{mM} \mathrm{NaCl}$ respectively. Salt damage to the crops has been attributed to combination of several factor including osmotic stress and the accumulation of toxic ions According to Kagan et al. (2010) those genotypes are having lower indices (15\%) it's classify 

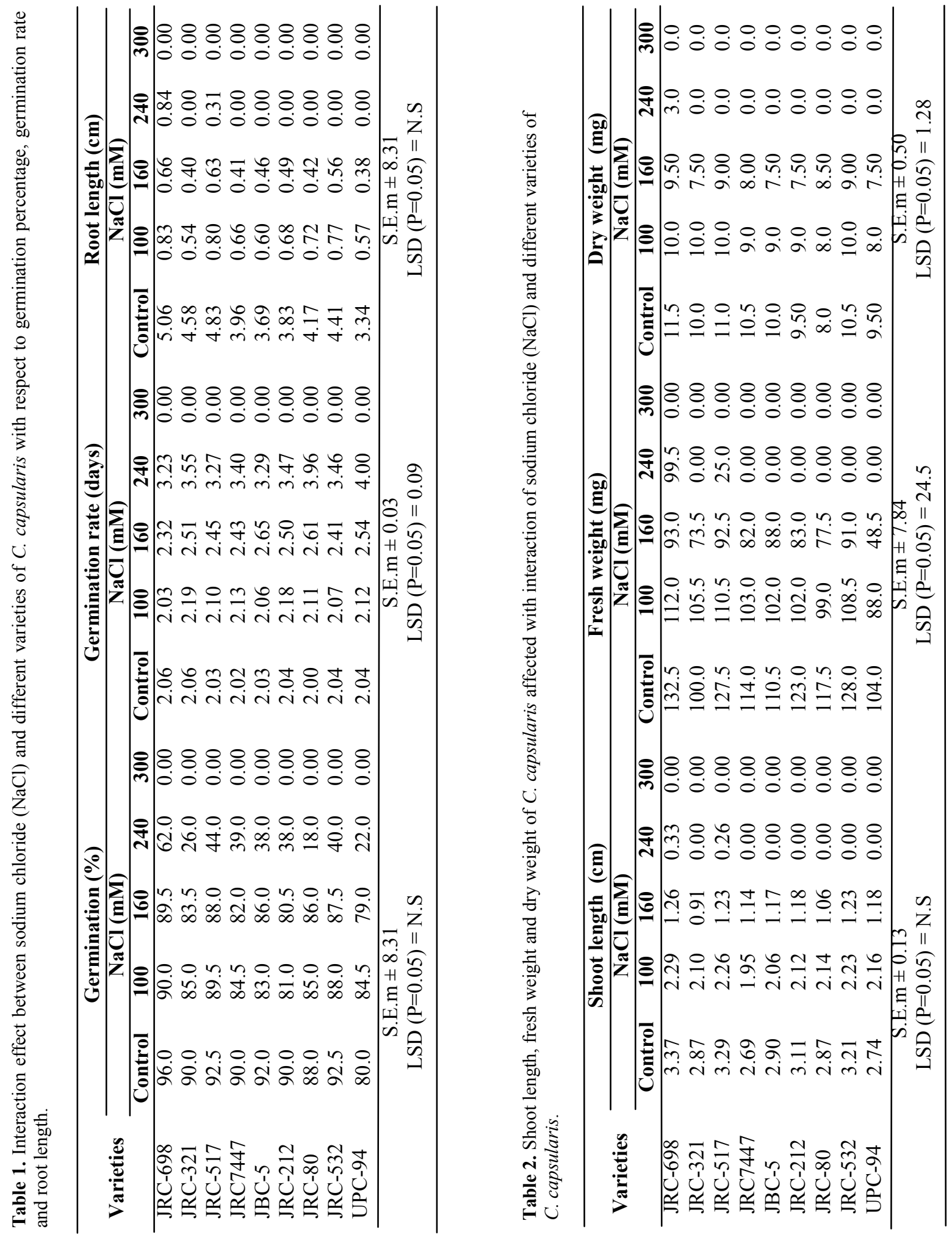
Table 3. Interaction effect of sodium chloride $(\mathrm{NaCl})$ and different varieties of $C$. capsularis with respect to salt tolerance index for different varieties of jute.

\begin{tabular}{lccccc}
\hline & \multicolumn{5}{c}{ Salt tolerance index (STI) (\%) } \\
\cline { 2 - 6 } Varieties & \multicolumn{5}{c}{ NaCl (mM) } \\
\cline { 2 - 6 } & Control & $\mathbf{1 0 0}$ & $\mathbf{1 6 0}$ & $\mathbf{2 4 0}$ & $\mathbf{3 0 0}$ \\
\hline JRC-698 & 100.0 & 90.9 & 81.8 & 0.00 & 0.00 \\
JRC-321 & 100.0 & 80.0 & 75.0 & 0.00 & 0.00 \\
JRC-517 & 100.0 & 80.0 & 90.0 & 0.00 & 0.00 \\
JRC7447 & 100.0 & 66.6 & 55.5 & 0.00 & 0.00 \\
JBC-5 & 95.4 & 81.8 & 36.3 & 0.00 & 50.0 \\
JRC-212 & 90.0 & 83.8 & 40.0 & 0.00 & 50.0 \\
JRC-80 & 88.8 & 72.1 & 33.0 & 0.00 & 50.0 \\
JRC-532 & 95.4 & 90.9 & 45.0 & 0.00 & 50.0 \\
UPC-94 & 85.0 & 60.0 & 15.0 & 0.00 & 0.00 \\
\hline \multicolumn{7}{c}{ S.E.m \pm 4.58} \\
LSD (P=0.05) = N.S \\
\hline \multicolumn{7}{c}{. }
\end{tabular}

as moderately tolerant. Hence, UPC-94 (15\%) and was evaluated as the moderately tolerant variety.

\section{Conclusion}

Germination and seedling stage of white jute were sensitive to salinity and with increasing the $\mathrm{NaCl}$ concentration all the growth character were decreased. Germination of all $C$. capsularis varieties was completely inhibited at higher concentration $(300 \mathrm{mM}$ $\mathrm{NaCl}$ ) and at lower concentration these parameter varied with varieties. Variety JRC-698 recorded the higher germination percentage, root and shoot length, while UPC-94 recorded the lowest germination percentage, root and shoot length. Salt tolerance index of C. capsularis was observed highest in varieties JRC- 517, JRC-698 and UPC-94 had recorded lower salt tolerance index than other varieties. Among the nine selected white jute varieties, JRC-698 and JRC-517 were relatively more tolerant to the salt stress than the other verities. Hence, these varieties can be grown the salt concentration upto $160 \mathrm{mM}$ of $\mathrm{NaCl}$.

\section{REFERENCES}

Abass, S.M and Latif, H.H. (2005). Germination and protein patterns of some genotypes of two species of jute as affected by $\mathrm{NaCl}$ stress. Pakistan Journal of Biological Sciences, (8): 227-234.

Almansouri, M., Kinet, J.M. and Lutts. S. (2001). Effect of salt and osmatic stress on germination in durum wheat (Triticum aestivam). Plant Soil, (230):243-254.

Anonymous (2010). Agriculture at nature's mercy. Info change News and Feature, July 2010.(http:// infochangeindia.org/index 2.php?option $=$ com_content\& do_pdf $=1 \&$ id $=8397$.
Bohnert, H.J., Nelson, D. and Jensen, R.G. (1995). Adoptions to environmental stresses. Plant Cell, (7): 1099-1111.

FAO (2005). Global network on integrated soil management for sustainable use of salt affected soils, Rome, Italy. FAO Land and Plant Nutrition Management Service.

Fitter, A.H. and Hay, R.K.M. (1987). Environmental physiology of plants. $2^{\text {nd }}$ Edition Academic press. Landon.

Hongyu M., Ruifang, Y., Zhankui,W., Tian,Y., Yuying, J., Hanyan, G., Xiansheng. W. and Hao,M. (2011). Screening of salinity tolerant jute (Corchorus capsularis and Corchorus olitorius) genotypes via phenotypic and physiology-assisted procedures. Pakistan Journal of Botany, 43(6): 2655-2660.

Islam, S., Azam, M.S., Sazia, S., Abu, A.S., Maksudul, A., Shamim, R., Ahmed, R. and. Khan, H. (2013). Improved salt tolerance of jute plants expressing the kat $E$ gene from Escherichia coli. Turkish Journal of Biology, 37: 206-211.

Kagan, K., Tolga, K., Adil, B. and Mevlut, A. (2010). Determination of salinity tolerance of some lentil (Lens culinaris M.) varieties. Journal of Food, Agriculture and Environment, 8 (1):140-143.

Ma, H.Y., Wang, R.J., Wang, X.S. and Ma, H. (2009). Identification and evaluation of salt tolerance of jute germplasm during germination and seedling periods. Journal of plant genetic resources, 10(2):236-243.

Maji, B., Sahu, N.C., Das, I., Saha, S., Sarkar, S. and Saha, S. (2012). Soil fertility and management for productivity enhancement of jute undersome constrained acidic soils of West Bengal. Indian Journal of Agricultural Sciences, 82 (4): 345-50.

Munns, R. (2005). Genes and salt tolerance: bringing them together. New Phytologist, 167: 645-663.

Munns, R. and Tester, M. (2008). Mechanisms of salinity tolerance. Annual Review of Plant Biology, 59: 651-681.

Pieper, A. (1952). Das saatgut. V.P. Darey Berlin, Hamburg.

Sarkar, S. (2008). Good practices for jute and allied fibre crops. In: Souvenir, International Symposium on jute and allied fibre Production, Utilization and Marketing, pp 1-3. Organized by Indian Fibre Society (Eastern Region). Kolkata, 9-12 January.

Seghatoleslami, M.J. (2010). Effect of salinity on germination of satureja hortensis L., Cichorium intybus L., and Cynara scolymus L., Iranian Journal of Agricultural Research, 8(5): 818-823.

Wang, M.C., Peng, Z.Y., Li, C.L., Li, F., Liu, C. and Xia, G.M. (2008). Proteomic analysis on a high salt tolerance introgression strain of Triticum aestivum / Thinopyrumponticum. Proteomics, 8:1479-1489.

Younis, M.E., Hasaneen, M.N.A., Ahmed, A.R and El-Bialy, D.M.A, (2008). Plant growth, metabolisim and adoption in relation to strees condition. XXI. Reversal of harmful $\mathrm{NaCl}$ effects in lettuce plants by foliar application with urea. Australian Journal of Crop Science, 2(2): 83-95. 